\title{
Interfaith Marriages Based on Positive Law in Indonesia and Private International Law Principles
}

\author{
Benny Krestian Heriawanto \\ Faculty of Law, Universitas Islam Malang, Kota Malang 65144, Indonesia. \\ E-mail : bennyheriawanto@unisma.ac.id.
}

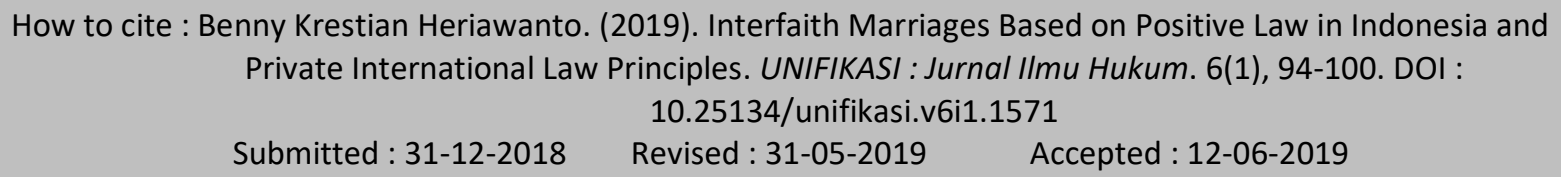

Abstract : This study intends to find out the legitimacy of interfaith marriages according to positive law in Indonesia and private international law, especially marriages held abroad between Indonesian citizens or with a foreign national. The method used in this study was a normative juridical through a legislation approach. Basically, marriages held in Indonesia must follow the provisions of Article 2 jo. Article 56 of Law No. 1 of 1974 concerning marriage. The results of the analysis revealed that interfaith marriages cannot be held either in Indonesia or abroad since they conflict with the principles of private international law and positive law in Indonesia.

Keywords: Legitimacy; Interfaith Marriage; Private International Law

\section{Perkawinan Beda Agama menurut Hukum Positif Indonesia dan Asas Asas Hukum Perdata Internasional}

Abstrak : Tulisan ini disusun untuk mengetahui keabsahan perkawinan beda agama menurut hukum positif Indonesia dan hukum perdata internasional khususnya perkawinan yang dilangsungkan di luar negeri di antara mereka warga negara Indonesia atau dengan seorang warga negara asing. Metode penelitian yang digunakan yaitu yuridis normatif melalui pendekatan perundang undangan, perkawinan yang dilangsungkan di Indonesia harus memenuhi ketentuan Pasal 2 jo. Pasal 56 Undang undang Nomor 1 Tahun 1974 tentang perkawinan. Hasil kajian dan analisis dapat disimpulkan bahwa perkawinan beda agama tidak dapat dilangsungkan baik di dalam maupun di luar negeri karena bertentangan dengan asas asas hukum perdata internasional dan hukum positif Indonesia.

Kata Kunci: Keabsahan, Perkawinan Beda Agama, Hukum Perdata Internasional

\section{INTRODUCTION}

Marriage is a necessity for the continuation of human life, especially when marriage is understood as an effort to regenerate. A human being born in the world will grow along with the time, until one time his life will end in this world. Hence, giving birth to a caliph (as a substitute) is absolutely necessary for the continuation of human life. In Islam, marriage is intended to justify sexual relations as human nature as well as to form a family based on love which not only aims at regenerating process but also at obtaining legitimate offspring. According to Imam Ghazali, marriage basically has a purpose to obtain legitimate offspring, to develop human tribes, to fulfill the instinctive demands of human life as well as to protect people from crime and damage. ${ }^{1}$ In Islam, marriage is defined as a legal event in the form of akad or agreement made between a man and a woman on the basis of voluntary and pleasure to form a family that is full of love and based on ways that are blessed by Allah SWT. ${ }^{2}$

According to Catholic Law, marriage is a fellowship of life between a man and a woman on the basis of a total bond of love with the irrevocably agreement. According to Hinduism law, marriage (wiwaha) is a bond between a man and a woman as a husband and a wife to arrange proper sexual relations in order to get offspring who will save the spirits of his parents from hell; it is carried out in

\footnotetext{
${ }^{1}$ Soemiyati, Hukum Perkawinan Islam dan Undang undang Perkawinan (Undang undang No. 1 Tahun 1974 tentang Perkawinan), Yogyakarta; Liberty, 1999. Hlm. 12.

${ }^{2}$ Ibid. Hlm. 8
} 
ritual ceremonies according to Hinduism, named Weda Smrti. According to Buddhist law, marriage is an inner and outer bond between a man as a husband and a woman as a wife based on love (metta), affection (karuna) and sense of continuity (mudita) with the aim to form a happy family blessed by Sanghyang Adi Buddha/God Almighty, and Bodhi-satwa-Mahasatwa. ${ }^{3}$

Religion takes its role in determining and regulating marriages as part of religious teachings. Therefore, marriages cannot only be seen as civil relations that only have social implications, but must also be understood as part of the worship concept based on the nature of religiosity. In addition to legal norms, religious norms as one of the social norms play a crucial role in the formation of families through sacred marital institutions. It is in line with the Pancasila philosophy in which its value emphasizes that all acts carried out by Indonesian must be based on the values of the God Almighty. This is explicitly illustrated in Article 1 point 1 of Law No. 1 of 1974 concerning Marriage that "marriage is a physical bond between a man and a woman as a husband and a wife with the aim of forming a happy and eternal family based on the God Almighty". 4

In its development, marriage is recognized as a human right which is explicitly stated in Article 10 of Law No. 39 of 1999 concerning Human Rights (hereinafter referred to as the Human Rights Act). This article emphasizes that every person has the right to form a family and continue his offspring through a legal marriage. The legal marriage can only take place on the basis of will of the prospective husband and wife in accordance with the legislations. Article 10 of the Human Rights Act emphasizes that forming a family and continuing marriage in a marriage institution are human rights that must be respected and upheld as basic rights (fundamental recognition of human existence and survival). For anyone who wants to have a marriage can not be prevented or even forced to marry someone he/she does not want to. Yet, this right is not absolutely valid and enforceable since it is also limited by legislations (Article 73 of the Human Rights Act).

With the development of information technology, in this modern era, humans' interaction space can no longer be limited and be blocked. They move without limits, interact without knowing the boundaries of regions, countries and even continents. Thus, there are found various mixed marriages between those of different nationalities, different ethnicity, race or religion. Some of them even are not only different religions, but also different nationalities. These conditions result in legal problems over the legitimacy of interfaith marriages, especially from the perspective of private international law since there are found many legal subjects who carry out interfaith marriages hoping to legalize their marriages held abroad. The theoretical study of law must be a means to find the truth. Thus, through the law, legal conflicts should be able to overcome. It is well known that Indonesia is a state of law which places law in a high position (rule of law). As stated by Ann Van Wynen Thomas, law is the arrangement of the authorities to resolve legal relations in order to realize public order. ${ }^{5}$

Private international law, also known as conflict of law, recognizes several principles that are relevant to marriages carried out by those who are subject to different legal systems. These principles can serve as a basis for analyzing and reviewing, and then finding out whether interfaith marriages held abroad are in accordance with the principles of marriage law known in private international law and can interfaith marriages then be legitimated under positive law in Indonesia? Briefly, this study aims to find out the legitimacy of interfaith marriages according to private international law and positive law in

\footnotetext{
${ }^{3}$ H. Hilman Hadikusuma, Hukum Perkawinan Indonesia Menurut: Perundangan Hukum Adat Hukum Agama, Bandung; Mandar Maju, 1990. Hlm. 11-12.

${ }^{4}$ Laurensius Arliman S, Perlindungan Hukum Bagi Anak Dalam Perspektif Pancasila Dan Bela Negara, Unifikasi : Jurnal Ilmu Hukum, Vol. 5, No. 1, Januari 2018, Hlm. 60.

${ }^{5}$ Komar Hidayat, Yunusrul Zen dan Diding Rahmat, Analisis Yuridis Terhadap Kebijakan Diversi Pemerintah Daerah Dalam Perlindungan Anak Di Kabupaten Kuningan, Unifikasi : Jurnal Ilmu Hukum, Vol. 4, No. 2, Juli 2017. Hlm. 89.
} 
Indonesia, especially for interfaith marriages held abroad either between Indonesian citizens or with a foreign national.

\section{RESEARCH METHODS}

This study was a normative legal research by applying the statute approach (Marzuki, 2008) to analyze the provisions relating to interfaith marriages contained in Law No. 1 of 1974 concerning Marriage and other legislations. Besides, conceptual approach was also utilized to analyze the concepts found in the legislations.

\section{RESULTS AND DISCUSSION}

\section{Interfaith Marriages According to Private International Law}

Private international law works when there are people with different legal system committing one legal act. Private international law works to provide a solution for that conflict. One of the objects of private international law is marriage as a plural legal act done across space and ideology. In the perspective of private international law, marriage as a legal act can be the object of private international law if the marriage is; 1) carried out by two different domicile persons and each of them is subject to different legal rules or legal systems and 2) a different nationality couple. ${ }^{6}$ Law No. 1 of 1974 concerning Marriage recognizes mixed marriages in the second form.

Not all mixed marriages are interfaith marriages, but interfaith marriages are mixed marriages. There is even an opinion stating that interfaith marriages are part of mixed marriages. ${ }^{7}$ This can be interpreted through the provisions of Article 57 of Law No. 1 of 1974 concerning Marriage that mixed marriages are marriages between two people of different religions and/or different nationalities. ${ }^{8}$ The legitimacy of a marriage is generally distinguished by material validity and formal validity in which both validities are subject to different principles. For material validity of marriage, several principles of private international law that can be used are as follows:

First is the principle of lex loci celebrationsis. According to this principle, the material validity of a marriage is determined by the rules that apply in the place where the marriage takes place. For example, if an Indonesian citizen marries B, a Brunai Darusaalam citizen, in Australia, then the material validity of the marriage is determined by the marriage law applicable in Australia. Second, the principle stating that the material validity of a marriage is determined by the legal system applicable in the country of origin of each party. For example, if A is an Indonesian citizen, married to a citizen of Brunei Darussalam, then the material validity of marriage for $\mathrm{A}$ is determined by the applicable marriage law in Indonesia and for B is determined by the applicable marriage law in Brunei.

Third, the principle stating that the material validity of a marriage is determined by the applicable law in the place of the parties domiciled. In this principle, it is assumed that those who will carry out the marriage do not live in the country where they are citizens. For example, A is an Indonesian citizen and domiciled in Singapore. B is citizen of Brunei Darussalam and domiciled in Singapore. Both of them have a marriage in Australia. According to this principle, the material validity of the marriage is determined by the applicable marriage law in Singapore where both parties are domiciled. Fourth, the principle stating that the material validity of a marriage is determined based on the principle of lex loci celebrationis, without ignoring the material validity of the marriage specified in the applicable marriage

${ }^{6}$ Bayu Seto, Hardjowahono, Dasar dasar Hukum Perdata Internasional, Bandung; Citra Aditya Bakti, 2013. Hlm. 265.

${ }^{7}$ Danu Aris Setiyanto, Perkawinan Beda Agama Pasca Putusan Mahkamah Konstitusi Nomor 68/PUU-XII/2014 Dalam Perspektif HAM, Al-Ahwal, Vol. 9, No. 1, Juni 2016. Hlm. 15.

${ }^{8}$ M. Nur Kholis Al Amin, Perkawinan Campuran Dalam Kajian Perkembangan Hukum: Antara Perkawinan Beda Agama Dan Perkawinan Beda Kewarganegaraan di Indonesia, Al-Ahwal, Vol. 9, No. 1, Juni 2016. Hlm. 214. 
law where the marriage takes place as well as where both parties come from. For example, if an Indonesian citizen married to a Brunei Darussalam citizen in Australia, then the legitimacy of the marriage is determined by the applicable marriage laws in Australia as well as the applicable marriage laws in Indonesia and Brunei Darussalam. ${ }^{9}$

With regard to the formal validity of marriage, in general, each country applies the locus regit actum principle in which the legitimacy of a marriage is based on the law applicable in the country where the marriage takes place. It means that, in relation to the formal validity of marriage, the state generally refers to or is subject to applicable law where the marriage takes place. The choice of legal principles applied in mixed marriages as objects of conflict of law strongly depends on the legal politics applicable in a country. Some countries are subject to the principle of lex loci celebrationis, while some others are subject to other principles.

\section{Interfaith Marriages According to Positive Law in Indonesia}

Interfaith marriage in Indonesia is actually not a new issue. There even have been laws governing interfaith marriages since the days of the Dutch East Indies. Referring to the previous provisions, it can be justified because Article 66 of Law No. 1 of 1974 concerning marriage emphasizes that as long as it is not specifically regulated in the Marriage Law, all provisions contained in the Civil Code (BurgelijkWetboek), Indonesian Christian Marriage Ordinances (Huwelijk Ordanantie Christen Indonesia, 1933, No.74), Mixed Marriage Regulations (Regeling op gemeng de Huwelijken S. of 1898, No. 158), and other Regulations are declared to remain applicable. Article 1 of Regeling op gemeng de Huwelijken S. of 1898 No. 158 states that marriages between people who are in Indonesia, but subject to different laws are called mixed marriages (Huwelijken tusschen personen, die in Indonesië aan een verschillend recht onderworpen zijn, worden gemengde huwelijken genoemd). In general, there are at least four types of mixed marriages recognized in Regeling op gemeng de Huwelijken S. of 1898 No. 158, including international mixed marriages, mixed marriages between places, mixed marriages between groups, and interfaith marriages. ${ }^{10}$

Article 7 paragraph 2 of Regeling op gemeng de Huwelijken S. of 1898 No. 158 emphasizes that differences in religion, nationality or offspring cannot be a barrier to marriage (Verschil van godsdienst, landaard of afkomst kan nimmer als beletsel tegen het huwelijk gelden). Therefore, Article 6 paragraph (1) of Regeling op gemeng de Huwelijken S. of 1898 No. 158 regulates that such mixed marriages must be carried out according to the law applicable to the husband without prejudice to the consent of the husband and wife (De voltrekking van gemengde huwelijken geschiedt volgens het voor den man geldende recht, behoudens de toestem). This can be understood in a view that laws of the Dutch East Indies Government are based on the principle of individualism as the basis of the birth of a secular state. Therefore, in the end, it is considered necessary to make changes to the marriage law in accordance with the values of Pancasila. In its development, along with the enactment of Law No. 1 of 1974 concerning Marriage, mixed marriages are regulated although not explicitly regulate interfaith marriages.

According to Article 2 of the Marriage Law, a marriage is declared illegitimate if it is declared illegitimate based on religion and the marriage will be considered legitimate if religion considers it legitimate. Article 2 of the Marriage Law includes religious norms as one of the determinants of the legitimacy of a marriage before the law. Based on its formation process, Paul Bohannan notes that; 1) the rule of law originating from the highest authority is applied to the community by taking into account the needs of the community (top-down) and 2) the rule of law originating from other social rules that apply in society. This type of rule of law is a rule that goes through a process of double legitimacy. In

\footnotetext{
${ }^{9}$ Ibid.

${ }^{10}$ Danu Aris Setiyanto, Loc. Cit.
} 
other words, the rule of law is a rule originating from the moral, religious and/or modesty rules so that the legal norms are also moral, religious and modesty norms. In this type of the rule of law, Marriage Law can be understood in its application. ${ }^{11}$

On the basis of this rule of law, based on research that has been conducted previously, it is known that basically no religion can justify interfaith marriages or in other words, no religion can state that interfaith marriages can be carried out and admitted as a legitimate marriage. ${ }^{12}$ Based on the teachings of each religion as well as based on Article 2 paragraph 1 of Marriage Law, it can be concluded that interfaith marriages are not only declared illegitimate by religion, but can also be declared illegitimate by the State. Thus, interfaith marriages cannot take place in Indonesia. Every religion demands that marriages are carried out based on its respective religion. Islam which initially only forbade women to marry non-Muslim men either Ahlul Kitab or non-Ahlul Kitab, ${ }^{13}$ in the end, it no longer distinguishes between samawi religion and ardhi religion. The Indonesian Ulema Council has decided that interfaith marriages are illegitimate. Likewise, the marriage of Muslim men to Ahlul Kitab women, according to qaul mu'tamad, is illegitimate. By considering the provisions of Article 4 concerning Compilation of Islamic Law, it can be concluded that interfaith marriages in Islam are absolutely prohibited. ${ }^{14}$

Similar to Islam, as stated by Hilman Hadikusuma, Catholicism requires that marriages can take place after the bride and groom have been baptized. Baptism is interpreted as a form of faith in the death, burial and resurrection of Jesus Christ. In the same sense, Hinduism law asserts that marriage is illegitimate if it is not carried out according to Hinduism religious marriage ceremonies. Moreover, Article 2 of the Indonesian Buddhist Marriage Law states that a marriage is declared to be legitimate if it is carried out according to the Buddhist marriage law; it is also no exception with the kong hu chu religion. ${ }^{15}$ Hence, the provisions of Article 7 paragraph 2 of Regeling op gemeng de Huwelijken S. of 1898 No. 158 can be declared invalid because it contradicts Article 2 paragraph 1 of the Marriage Law.

The next question is that whether interfaith marriages can be held abroad by subjecting to the principles known in private international law. Regarding this issue, Article 56 paragraph 1 of the Marriage Law has explicitly stated that marriage held abroad between two Indonesian citizens or an Indonesian citizen with a foreign national is legal if it is carried out according to the law applicable in the country where the marriage takes place and the Indonesian citizens do not violate the provisions of this Law. Based on this provision, it can be concluded that Indonesian legal politics adheres to the fourth principle known in private international law, namely the principle of lex loci celebrationis, without ignoring the material validity of the marriage specified in the marriage law applicable in the State of both parties. Thus, marriages that take place both in Indonesia and abroad must meet the conditions set by the country where the marriage takes place, and if he/she is an Indonesian citizen, then he/she must comply with all applicable provisions in Indonesia (all applicable provisions based on the Marriage Law), especially Article 2 paragraph 1 of the Marriage Law. Moreover, for Indonesian citizens who hold marriages abroad, they must also comply with all provisions stipulated in religious norms that explicitly prohibit interfaith marriages. Hence, interfaith marriages held abroad cannot be legalized because it contradicts Article 56 jo. Article 2 of the Marriage Law.

Based on the description, the author is in a view with Sri Wahyuni who states that interfaith marriages held abroad does not necessarily become the basis that such marriages are justified; bearing in mind that interfaith marriages are also recorded by the Department of Population and Civil

\footnotetext{
${ }^{11}$ Marwan Mas, Pengantar Ilmu Hukum, Bogor; Ghalia Indonesia, 2011. Hlm. 50

12 Jane Marlen Makalew, Akibat Hukum dari Perkawinan Beda Agama di Indonesia, Lex Privatum, Vol. 1, No. 2, April - Juni 2013. Hlm. 11-137.

13 Muhammad Ashsubli, Undang-Undang Perkawinan Dalam Pluralitas Hukum Agama(Judicial Review Pasal Perkawinan Beda Agama), Jurnal Cita Hukum, Vol. 3. No. 2, Desember 2015, Hlm. 295.

${ }^{14}$ Fatwa Majelis Ulama Indonesia Nomor: 4/Munas VII/MUI/8/2005 tentang Perkawinan Beda Agama

${ }^{15}$ H. Hilman Hadikusuma, Loc. Cit.
} 
Registration. Yet, with the principle of vested right, we must not ignore the importance of analyzing whether the marriage is contrary to the positive law in Indonesia (Article 56 paragraph 1 of the Marriage Law) or whether the marriage is carried out by people of different religions or not. This would be misleading if the recording is also recognized as a form of recognition of interfaith marriages as a legitimate act of law. ${ }^{16}$ Law No. 1 of 1974 concerning Marriage has closed the opportunity for interfaith marriages. Therefore, in its position, Law No. 1 of 1974 concerning Marriage must be understood as a law that plays a positive role as Roscoe Pound notes that it has a function of social engineering in order to understand and avoid interfaith marriage. ${ }^{17}$ Meanwhile, law enforcement becomes a necessity to ensure the implementation of these provisions so that the law is maintained and can directly benefit the community. The law must be able to control and manipulate the bad habits of the community. ${ }^{18}$

\section{CONCLUSION}

Based on the description, it can be concluded that interfaith marriages held both in Indonesia and abroad are illegitimate because Law No. 1 of 1974 concerning Marriage adheres to the principle of lex loci celebrationis, without ignoring the material validity of the marriage specified in the marriage law applicable in the State of both parties as one of the principles known in private international law.

\section{SUGGESTION}

Law for the prohibition of interfaith marriages needs to be enforced. Here, every marriage that takes place abroad must be recorded after firstly testing whether the marriage is in accordance with the positive law in Indonesia or violates the positive law applicable in Indonesia so that the recording of marriages held abroad do not seem to only fulfill administrative requirements and lead to the birth of aspirational and accommodating laws in accordance with the community mainstream.

\section{REFERENCES}

\section{Books}

Hardjowahono, B. S. 2013. Dasar Dasar Hukum Perdata Internasional. Bandung: Citra Aditya Bakti. Hadikusuma, H. 1990. Hukum Perkawinan Indonesia Menurut: Perundangan Hukum Adat Hukum Agama, Bandung: Mandar Maju.

Marzuki, P. M. 2008. Penelitian Hukum. Jakarta: Kencana Prenada Media Group.

Mas, M. 2004. Pengantar Ilmu Hukum. Bogor: Ghalia Indonesia.

Soemiyati, 1999, Hukum Perkawinan Islam dan Undang undang Perkawinan (Undang undang Nomor 1 Tahun 1974 tentang Perkawinan), Yogyakarta; Liberty.

Wahyuni, S. 2016. Nikah Beda Agama Kenapa ke Luar Negeri? Tangerang Selatan: Pustaka Alvabet.

\section{Journals}

Danu Aris Setiyanto. 2016. Perkawinan Beda Agama Pasca Putusan Mahkamah Konstitusi Nomor 68/PUU-XII/2014 Dalam Perspektif HAM, Al-Ahwal, Vol. 9, No. 1, Juni 2016.

Komar Hidayat, Yunusrul Zen dan Diding Rahmat. 2017. Analisis Yuridis Terhadap Kebijakan Diversi Pemerintah Daerah Dalam Perlindungan Anak Di Kabupaten Kuningan, Unifikasi : Jurnal Ilmu Hukum, Vol. 4, No. 2, Juli 2017.

\footnotetext{
${ }^{16}$ Sri Wahyuni, Nikah Beda Agama Kenapa ke Luar Negeri?, Tangerang Selatan, Alvabet, 2016. Hlm. 240-244.

${ }^{17}$ Suwari Akhmaddhian, Pengaruh Kebijakan Pemerintah Daerah Dalam Konservasi Sumber Daya Air Terhadap Kesadaran Lingkungan Masyarakat Kabupaten Kuningan, Jurnal Unifikasi, Vol. 04, Nomor 01, Januari 2017. Hlm. 9.

${ }^{18}$ Suwari Akhmaddhian, Implementasi Penegakan Hukum Lingkungan Pada Sektor Pertambangan Di Kabupaten Kuningan, Jurnal Unifikasi,Vol. 04, Nomor 01, Januari 2017. Hlm. 46-49.
} 
Laurensius Arliman S. 2018. Perlindungan Hukum Bagi Anak Dalam Perspektif Pancasila Dan Bela Negara, Unifikasi : Jurnal Ilmu Hukum, Vol. 5, No. 1, Januari 2018.

M. Nur Kholis Al Amin. 2016. Perkawinan Campuran Dalam Kajian Perkembangan Hukum: Antara Perkawinan Beda Agama Dan Perkawinan Beda Kewarganegaraan di Indonesia, Al-Ahwal, Vol. 9, No. 1, Juni 2016.

Makalew, J. M. (2013). Akibat Hukum dari Perkawinan Beda Agama di Indonesia. Lex Privatum, Vol. I, No. 2. April-Juni 2013.

Muhammad Ashsubli. 2015. Undang-Undang Perkawinan Dalam Pluralitas Hukum Agama (Judicial Review Pasal Perkawinan Beda Agama), Jurnal Cita Hukum, Vol. 3. No. 2, Desember 2015.

Suwari Akhmaddhian. 2017. Pengaruh Kebijakan Pemerintah Daerah Dalam Konservasi Sumber Daya Air Terhadap Kesadaran Lingkungan Masyarakat Kabupaten Kuningan, Unifikasi : Jurnal Ilmu Hukum, Vol. 04, Nomor 01, Januari 2017.

Suwari Akhmaddhian. 2017. Implementasi Penegakan Hukum Lingkungan Pada Sektor Pertambangan Di Kabupaten Kuningan, Unifikasi : Jurnal Ilmu Hukum, Vol. 04, Nomor 01, Januari 2017.

\section{Legislations}

Undang undang Nomor 1 Tahun 1974 tentang Perkawinan

Undang undang Nomor 39 Tahun 1999 tentang Hak Asasi Manusia

Regeling op Gemeng de Huwelijken S.1898 No.158

Instruksi Presiden Republik Indonesia Nomor 1 Tahun 1991 tentang Kompilasi Hukum Islam. 